DOI: 10.46340/ephd.2021.7.3.19

\author{
Ihor Spaskyi \\ ORCID ID: https://orcid.org/0000-0003-0480-9264 \\ Odesa I.I. Mechnikov National University, Ukraine
}

\title{
SOFIA ONTOLOGIZATION OF THE ECONOMY IN THE PRACTICES OF PHILOSOPHICAL REFLECTION OF ECONOMIC THINKING
}

\author{
Irop Спаський \\ Одеський національний університет ім. І.І. Мечникова, Україна

\section{ФІЛОСОФСЬКО-МЕТОДОЛОГІЧНІ АСПЕКТИ СОФІЙНОЇ ОНТОЛОГІЗАЦІЇ ГОСПОДАРСТВА У СУЧАСНИХ УМОВАХ}

The current systemic crisis has undoubtedly affected both theoretical knowledge and economic life itself. This causes the urgency of the revision of the historical heritage of economic thought as a whole and its individual areas. As well as the implementation of mental reflection on the subject of cognitive abilities and limitations. Analysis of economic thought in historical retrospect highlighted several theoretical and methodological problems. This is the so-called isolation of theoretical calculations from such important aspects of economics as economic anthropology and analysis of social, environmental, and even psychophysiological aspects of reality.

The article considers the problem of Sofia ontology in the practices of philosophical reflection of thinking. The Sofia ontologization of the economy can be defined as a set of philosophical reflections of the Sofia experiences in the context of the economy. The author is based on the practices of the Sofia ontologization, existing in the tradition of the philosophy of economy. This provides opportunities to increase the heuristic potential of economic thinking and give it a new perspective of energy and meaning. Sophia's ontologization of economic thinking can, according to the author, overcome some totalitarianism present in traditional economic thought.

The practices of philosophical reflection of economic thinking co-create, on the one hand, the definition of thought moves that arise both within certain schools of economic thought. On the other hand, there is an opportunity to practice multidimensional thinking in economic theory. Which in general is aimed at improving the quality of economic thinking and opportunities for its practice.

Sophia's ethics and aesthetics of thinking provide certain guidelines for the quality and depth of economic thinking. The practices of the Sophian ontologization of thinking expand its heuristic potentials, and additionally stimulate thought processes through energetic and meaningful initiation.

Sophia's ontologization of the economy as a whole reveals the methodological principle of omnipresence. Which provides an opportunity to fill the gaps in thought that exist in economic thinking in general and various reflections of economic thought. This provides an opportunity to significantly expand the heuristic potential of philosophical reflections on the theory of economics and certain areas of economic thought.

Keywords: economic thinking, reflection of economic thinking, theory of fixed capital, methodology of economic science.

У межах економічної науки використання практик рефлексії мислення здійснюється дуже зрідка. Зокрема, практики рефлексії мислення спроможні значно підвищити якість та результативність мислення шляхом розкриття певних мисленнєвих обмежень та їх поступового коректування.

Звертання до філософської рефлексії економічної думки та здійснення мисленнєвої процедури онтологізації, грунтуючись на дослідженнях філософії господарства, спрямовано на вирішення цих проблем. 
Сучасні дослідження економічного мислення та можливостей його рефлексії за останні десятиріччя поповнені популяризацією відкриттів у нейрофізіології та нейропсихології. Це надає можливості зробити процеси рефлексії мислення більш обгрунтованими, глибокими та багатомірними.

Очевидним $є$ факт, що економічна думка продукується в процесі мислення економістатеоретика. 3'ясування особливостей економічного мислення, статусу мислячого, особистісних та історичних контекстів, у яких народжується думка, прояснює і конкретизує теоретичні конструкти i цілісні теорії. В.С. Біблер ${ }^{1}$ розкриває творче вимірювання мислення. Економічне мислення також може бути розглянуто в контексті даних аспектів. В. Медінцев безпосередньо актуалізує проблему «Мислення теоретика нового часу» ${ }^{2}$. Робота К.А. Улибіна ${ }^{3}$ розкриває проблематику сутності, ролі та формування економічного мислення в історичній перспективі. Даній проблематиці також присвячена робота А.Ю. Архипова ${ }^{4}$, в якій також розкривається зміст економічного мислення в традиції економічної думки.

На стиках дискурсів і парадигм, властивих тій чи іншій теорії, кажучи мовою М. Хайдеггера, народжується розумовий евристичний просвіт, прямуючи до якого дослідник народжує нове знання. Це повною мірою стосується як теорії основного капіталу в цілому, так і її граней, властивих різним школам. Тому, розглядаючи теоретичну думку, узагальнюючу проблематику основного капіталу, відкривається евристичний ресурс теорії і, крім того, відкриваються кордони пізнання.

Теоретичне мислення в економічній науці має свою логіку й особливості. Не всяке економічне мислення має статус теоретичного. Наприклад, у роботі «Економічний образ мислення» П. Хейне 5 по суті розглядається суміш між побутовим і схематично-навчальним розумінням економічного мислення, яке навряд чи може бути названо економічною теорією. Проблеми економічного мислення в теорії розкриває М. Блауг ${ }^{6}$, а також С. Фішер з колективом авторів ${ }^{7}$.

Не вирішеною залишається проблема використання в економічному мисленні практик його софійної онтологізації з метою підвищення евристичного потенціалу.

Господарські процеси можна розкрити як з позиції побутового економічного мислення, так і 3 позиції теоретичного мислення. Можливо також певне змішування даних видів мислення. Сучасні теоретики, як підкреслює В.А. Медінцев ${ }^{8}$, у своій розумовій діяльності орієнтовані на практики методологічного синтезу, міждисциплінарних $\mathrm{i}$ трансдисциплінарних інструментів пізнання. Причини такого стану речей розкриває Н.I. Чернецька в «типологічному і рівневому підходах до мислення як теоретико-методологічних основах інтегральної концепції творчого мислення» ${ }^{9}$. М. Н. Коркоценко, роблячи огляд визначень категорії «економічне мислення» в науковій літературі, показує теоретичні й побутові домінанти в роботах різних економістів-теоретиків, визначаючи економічне мислення в достатньому охопленні: «Економічне мислення - це категорія, яка може бути розглянута тільки в комплексі підходів різних гуманітарних галузей, на основі власного практичного досвіду людини і сформованого світогляду. Об'єктивний аналіз сучасних подій і ситуацій

\footnotetext{
${ }^{1}$ Библер, В. С. (1975). Мышление как творчество. Москва : Политиздат.

2 Мединцев, В. А. (2018). Мышление теоретика нового времени. Восьмая международная конференция по когнитивной науке: Тезисы докладов. Светлогорск, 18-21 октября 2018 г. Москва: Институт психологии РАН».

${ }^{3}$ Улыбин, К. А. (1989). Современное экономическое мышление: политико-экономические аспекты исследования и формирования: автореферат диссертации на соискание научной степени доктора экономических наук. Москва: Институт экономики АН СССР.

${ }^{4}$ Архипов, А. Ю. (1999). Современное экономическое мышление (Вопросы теории и практики развития): диссертация на соискание научной степени доктора экономических наук. Ростов-на-Дону: Ростовский Государственный Университет.

5 Хейне, П. (1991). Экономический образ мышления. Московский Либертариум <http://libertarium.ru/lib_thinking> (2021, серпень, 31).

${ }^{6}$ Блауг, М. (2004). Методология экономической науки, или Как экономисты объясняют. Москва: Журнал Вопросы экономики, 12; Блауг, М. (1994). Экономическая жизнь в ретроспективе. Москва: Дело Лтд, 6-7. ${ }^{7}$ Фишер С., Рудигер Д., Шмалензи Р. (1995). Экономика. Москва: Дело Лтд, 28.

${ }^{8}$ Мединцев, В.А. (2018). Мышление теоретика нового времени. Восьмая международная конференция по когнитивной науке: Тезисы докладов. Светлогорск, 18-21 октября 2018 г. Москва: Институт психологии PAH».

9 Чернецкая, Н. И. (2011). Типологический и уровневый подходы к мышлению как теоретико-методологические основания интегральной концепции творческого мышления. Вестник Сургутского государственного педагогического университета, 3, 5-9.
} 
3 практичного життя можливий тільки в поєднанні 3 теоретичними питаннями і методологічною базою. Справжні причини проблеми полягають в історичних особливостях розвитку суспільних відносин, центром інтересів яких виступає сама людина і її прагнення до чистої вигоди в різних формах. Економічне мислення визначається свідомістю людини і призводить до певного способу економічної поведінки. Логічний зв'язок сучасних подій та історичних процесів доводить необхідність системного аналізу і детального розгляду всіх процесів господарського життя суб'єктів економіки і економічної політики суспільства». ${ }^{2}$ Розгляд феноменів економічної думки, що розгортаються в просторі історії, вимагає аналізу як самого поняття мислення, так і його різновиду економічного мислення. Здатність людського мислення щодо ототожнення, узагальнення і абстрагування дозволяє в процесі пізнання піднятися над емпіричними спостереженнями і багатогранно усвідомити досліджуваний об'єкт, процес, явище об'єктивної дійсності. Це можливо завдяки особливій функції людської свідомості - абстрактного мислення. В економічній теорії, завдяки багатогранності предмета дослідження, абстрактне мислення має особливе значення. «Не індукція», спрямована на відшукання абстракції, висловлює «загальне» для всіх окремих випадків, а поглиблений аналіз одного окремого випадку, спрямований на те, щоб виявити шуканий процес в його «чистому вигляді» ${ }^{2}$. Зазвичай такий метод відкриває зовсім інший обсяг пізнання, дозволяє осягнути внутрішню логіку об'єкта пізнання. Під абстрактним розуміється цілісне уявлення про об'єкт дослідження, що виникає у свідомості людини в процесі включення особливої функції розуму - абстрактного мислення. Під конкретним - емпіричні спостереження за явищами дійсності на різних рівнях їх протікання.

Цей підхід має дуже багату онтологічну основу, перегукується з традицією наукового мислення Стародавнього Світу. Яскравий приклад - еврика Архімеда, яка дала назву евристичному пізнанню, по суті стала другою назвою абстрактного мислення. Наприклад в Стародавній Індії такий спосіб мислення називався самадхи. Абстрактне мислення простежується у філософській традиції ідеалізму, в системах I. Канта і Г. Гегеля. Ідея університету та ії розгортання на просторах Свропи з XII в. також базується перш за все на активізації абстрактного мислення. Про це свідчить дослідження В. Гумбольдта 3 , Дж. Ньюмена ${ }^{4}$ і К. Ясперса 5 .

Стаття, присвячена мисленню в «Новій філософської енциклопедії» ${ }^{6}$, дає достатньо повну аналітичну картину феномена мислення на різних рівнях його перебігу. В.А. Лекторский визначає мислення як «... процес вирішення проблем, що виражається в переході від умов, які задають проблему, до отримання результату» i «передбачає активну конструктивну діяльність 3 переструктурування вихідних даних, їх розчленування, синтезування та доповнення» ${ }^{7}$. Таке визначення можна застосувати і до економічного мислення. У роботі П. Хейне «Економічний образ мислення» ${ }^{8}$ економічне мислення розуміється як погляд на речі з позиції вигод і збитків. Тобто робиться акцент на економіко-аксіологічному вимірі мислення. В традиції марксистської політекономії економічне мислення розкривається в діалектичній логіці, абстрактному сходженні від абстрактного до конкретного, у взаємодії логічного та історичного. Школи економічної думки, попередні Марксу, що виникли окремо від марксизму і розвивалися незалежно, використовували різні форми економічної логіки. Наприклад, емпіричну чи побутову, підприємницько-діяльну, обумовлено-детерміновану, апологетичну, математичну і т. i.

Мислення - процес безсумнівно обумовлений як культурними формами, так і методологічним інструментарієм та існуючими парадигмами. Розглядаючи історичні зміни в галузі уявлень про мислення, стає можливим розкрити історичний вектор формування економічної думки.

\footnotetext{
${ }^{1}$ Коркоценко, М. Н. (2017). Обзор определений категории «экономическое мышление». Теория и практика общественного развития, 2. DOI: https://doi.org/10.24158/tipor.2017.2.10.

${ }^{2}$ Ильенков, Э. В. (1997). Диалектика абстрактного и конкретного в научно-теоретическом мышлении. Москва: РОССПЭН.

${ }^{3}$ Гумбольдт В. фон (2011). О внутренней и внешней организаџии высших научных учреждений в Берлине. Москва: Университетская идея в Российской империи XVIII-начала XX века: антология.

${ }^{4}$ Ньюмен, Дж. Г. (2006). Идея Университета. Минск: БГУ.

5 Ясперс, К. (2006). Идея университета. Минск: БГУ.

6 Лекторский, В. А. (2010). Мышление. Новая философская энциклопедия: В 4 томах. Москва: Мысль, II, $626-632$.

7 Там само, 626

${ }^{8}$ Хейне, П. (1991). Экономический образ мышления. Московский Либертариум

<http://libertarium.ru/lib_thinking> (2021, серпень, 31).
} 
Енциклопедичне розкриття феномену мислення з позиції поділу його спрямованості показує два основних напрямки. Це, по-перше, розуміння реальних обставин (світоустрою, обставин дії) i, подруге, досягнення конкретного практичного результату. В економічній думці перший тип мислення може розкриватися у формі буденного знання, міфологічного, філософського, наукового як на рівні теоретичних досліджень, так і емпіричного досвіду. Другий тип мислення розкривається у рішенні конкретних господарських проблем, завдань або проєктів майбутніх дій. В економічній науці ці два типи мислення проявляються в різних пропорціях на різних етапах. У деяких школах вони навіть витісняють один одного. У наш час спостерігається певний крен саме в практичне мислення. Однак системна криза, що охопила планету, поступово активізує дослідницький пошук у галузі теоретичних узагальнень високого рівня. Згідно «Нової філософської енциклопедії» обидва типи мислення взаємообумовлюють один одного.

Результатами мислення В.А. Лекторский вважає вироблення узагальнень. Для економічного мислення таким прикладом може бути теорія основного капіталу, розуміння того чи іншого предмета або події як на буденному, так на науковому рівні. Висновок може витікати як з формального, так $\mathrm{i}$ неформального міркування, а також з процесу проєктування. Рефлексія економічного мислення, заснована на сформованому ідейно-естетичному почутті мислячого, дає можливість розширити межі мислення і розсунути існуючі парадигмальні обмеження. Крім того, велику роль у процесі мислення відіграє соціальний та онтологічний статус мислячого, усвідомлення яких дозволяє мислячому внести відповідні корективи для підвищення якості мислення.

В енциклопедії мислення розкривається як взаємодія «внутрішніх процесів і зовнішніх дій» $\mathrm{i}$, крім того, поєднання чуттєвих і не чуттєвих компонентів. При аналізі текстів 3 корпусу історії економічної думки, використовуючи герменевтичний інструментарій, можна в роботах тих чи інших авторів простежити особливості процесу мислення, який протікав у момент їх створення. Це дає можливість як долучитися до традиції інакшості мислення, так і знайти основу для рефлексії власних розумових процесів.

Енциклопедія дає досить повний перелік можливих домінуючих компонент мислення. Коли базою мислення $\epsilon$ сприйняття, воно може протікати в переструктуруванні поля сприйняття $\mathrm{i}$ перцептивних дій, тобто зрушень внутрішнього простору, і також розкриватися в зовнішній суб'єктній діiі. У разі, коли основою мислення є наочні уявлення, процес протікає через комбінування уявлень, аналітичне членування і синтетичне об'єднання. Розумовий процес, заснований на словесних формах мови, може розкриватися як у вигляді внутрішнього мовлення або міркування «про себе», так і в процесі діалогу з іншими людьми. Такий тип мислення може бути абсолютно не наочним.

Автор енциклопедичної статті звертає увагу на те, що останній тип мислення історично прийнятий як такий, що виражає саму сутність мислення. Це, до речі, в повному обсязі проявляється в традиції економічної думки найрізноманітніших напрямків. I далі автор висловлює думку про те, що мислення передбачає дію в площинах вихідної ситуації та системи знакових засобів, що ії заміщує. Така ситуація породила зростаюче панування мислення тотожності і придушення мислення тонкого розрізнення. Це, з одного боку, ніби економить мислення - явище різко критиковане філософомметодологом А.М. П'ятигорським. I, з іншого боку, виникають суттєві обмеження на шляху мислення як у самому процесі мислення, так на рівні статусу мислячого.

Також важливим аспектом для розуміння феномену економічного мислення, що викристалізувалося в історичній традиції, є різні аспекти-галузі мислення, досліджувані відповідними науками. Наприклад, формальна логіка вивчає норми і правила міркування. Психологія розглядає вплив сучасного і минулого досвіду на установки суб'єкта та його емоційні стани. Філософія розглядає мислення з позиції можливості осягнення дійсності тими чи іншими розумовими стратегіями. 3 точки зору економіки, мислення має своїм предметом процеси суспільного відтворення, умови їх протікання, теорії, проєкти і конструкти, що описують ці процеси, а також пропонують ті чи інші форми зовнішнього впливу.

Мислення i досвід в традиції економічного мислення пов'язані безпосередньо. Це простежується як в історичній обумовленості народження тих чи інших концептів і теорій, так і у виборі способів мислення та конкретних методологій, грунтуючись на власному статусі економічно мислячого суб'єкта, а також і в його парадигмальній обумовленості (наприклад, обумовленість конвенційною Ньютон-картезіанською парадигмою).

Мислення, маючи емпіричну основу, пов'язано 3 порівнянням, аналітичним розчленуванням і з’єднує синтезом те, що було здобуто в дослідній подієвості, або комбінуванні уявлень, народжених 
3 минулих сприймань. В цьому випадку виникає абстрагування, тобто виявлення загальних ознак в конкретних предметах. Такі узагальнення виникають у так званому процесі дедукції. Такий тип мислення зазнав суттєвої критики. Виникла навіть назва емпіричної схоластики, що виразила крах емпірики як такої.

Традиція раціоналізму, характерна в певному сенсі і для економічної науки, протиставляє досвід мислення. 3 цієї позиції досвід не розкриває знання про реальність або може народити знання «смутні», яке необхідно розкрити в процесі мислення. У цьому сенсі досвід може лише підштовхнути мислення, яке здатне розгорнути додосвідні або «вроджені» ідеї або ідеї, дані в інтелектуальній інтуїції. По суті Г. Гегель поклав початок використанню діалектичного мислення в економічній думці. Гегель вважає, що мислення не протиставляється досвіду, і досвід служить мисленню опорою для того, щоб вийти за його межі і зробити похідним від самого себе. Те, що невідповідно розкривається емпірично, за Гегелем, відкривається в теперішньому вигляді мисленням. Таким чином, мислення в процесі практик саморозвитку звільняється від зв'язку із чуттєвістю, охоплюючи все різноманіття у вигляді особливого і одиничного.

Категоріальна призма характерна для економічного аналізу. На основі точного визначення економічних категорій будується традиція економічної думки в цілому і теорія основного капіталу зокрема. І. Кант розрізняє сприйняття і досвід. Сприйняття у Канта не пов'язане з мисленням, а ось досвід можливий лише будучи заснованим на використанні апріорних категорій розуму до чуттєвого сприйняття. Знання, таким чином, виникає в процесі категоріального аналізу емпірично пізнаваного різноманіття.

За Гуссерлем істинність продуктів мислення визначається тим, що результати розумової діяльності збігаються із переживанням феноменів очевидності. Такі особливості мислення характерні для державних діячів і для практиків-підприємці, для яких принцип знання-дії і практики як критерії істинності знання $є$ визначальним при здійсненні мислення.

Сучасні дослідження мислення в різних галузях знань підкреслюють неможливість виключно дослідної компоненти знання, яка б не залежала від домінант, збірок, схем, категорій, ідеалів, цінностей, смаків, культурних установок. У цьому сенсі сприйняття, що об'єднує активність і пасивність людини, розглядається як безпосередньо розумовий процес. Здійснюється взаємодія мислення і досвіду як в плані практізації результатів мислення, так і критичному осмисленні досвіду. В економічній думці прикладом такої взаємодії $\epsilon$ кейнсіанська теорія i практичні рішення Ф. Рузвельта на шляху виходу США з Великої Депресії, а також при створенні феноменів «економічного дива» у другій половині XX століття. Починаючи з другої половини XX століття, безперервно розвиваються і все більш широко використовуються так звані філософії бізнесу: «Кайдзен», «Бережливе виробництво», «Шість сигма», «Теорія мети» і багато інших. У цьому процесі проявляється значне посилення практичної домінанти мислення.

Вектор економічного мислення, починаючи зі Стародавнього Світу, можна простежити у характерному русі дослідницької уваги від побутового рівня повсякденності, характерні для давньоримської думки, і характерних спробах осмислити економічні процеси як частини Універсуму в давньоіндійських, давньокитайських і давньогрецьких текстах. Стародавній Світ і середньовіччя заклали кореневу систему дерева економічної думки розумової, різні напрями якої так чи інакше пов'язані з давніми традиціями осмислення економіки. Можна простежити вплив на діалектику Маркса ідей Канта і Гегеля. А на них - Аристотеля і древніх даосів, що розглядають буття на різних рівнях через взаємодію Інь і Ян. Хрематистика Аристотеля проросла в класичній школі, а потім і неокласиці, інституціоналізмі, кейнсианстві і навіть нейроекономіці і еконофізиці. Ідеї ж ойкумени Аристотеля проросли в російській домострої Кокорева і Посошкова, а потім і в філософії господарства і софіології. Проглядаються лінії ідейного наступництва, розкривають різноманітний простір економічної думки. Цей простір створювався мислителями, які були дітьми своїх епох. Їх миследіяльність визначалася генетикою, отриманим вихованням, онтологічним і соціальним статусом.

Дослідницьке розкриття багатовимірності простору економічної думки створює основу для рефлексії економічного мислення з метою підвищення його якості. Воно дозволяє виявити домінанти мислення, які існували та продовжують існувати, що визначають як хід економічної думки, так і особливості їі практізації.

Великий крок у розвитку пізнання в аспекті співвідношення абстрактного і конкретного пов'язаний з існуванням, починаючи 3 50-х років XX-го століття, Московського методологічного семінару, заснованого відомими методологами А.А. Зінов'євим, Г.П. Щедровицьким, 
Б.А. Грушиним, М.К. Мамардашвілі ${ }^{1}$. В рамках його діяльності розроблений системомиследіяльнісний підхід, і на його підставі розроблено методологічні організаційнодіяльнісні ігри, досвід яких свідчить про можливість створити умови для відтворення актів абстрактного мислення. Досвід вирішення багатьох економічних, управлінських та інших завдань свідчить про великі можливості абстрактного мислення ${ }^{2}$.

Дуже важливим виявляється і та обставина, що процес формування особливостей людської психіки розтягнутий у часі, особливо на перших вирішальних стадіях ${ }^{3}$, i тому може бути розглянутий під «лупою часу», як би за допомогою сповільненої кінозйомки .....

Сучасні дослідження в галузі нейрофізіології і нейропсихології розкривають особливості процесів, що протікають в мозку людини в ході науково-пізнавальної діяльності з використанням функцій абстрактного мислення. Значний прорив у питанні вивчення головного мозку стався, коли вперше застосували спосіб довгострокової імплантації в мозок людини електродів. Дослідження на рівні електричної активності головного мозку феномена осяяння, коли ідея з'являється як би 3 нізвідки. Н. Бехтерева, значно збагатили уявлення про функції абстрактного мислення ${ }^{5}$.

Використання діалектичної методології поступового сходження від абстрактного до конкретного з використанням принципу історизму дає можливість зобразити теоретичну сутність процесу відтворення основного капіталу, починаючи з визначення відтворення сутності основного капіталу, яка містить в згорнутому вигляді суперечності, які його рухають. Абстрактне обумовлює визначення єдності суперечливих явищ внаслідок існування взаємозв'язків, які об'єднують їх у цілісність і в рамках якої вони можуть взаємодіяти. Абстрагуюча діяльність мислення дозволяє встановити існуючі взаємозв'язки і поступово висловити їх розгорткою в єдності і суперечностях конкретних форм.

Процес пізнання починається з вихідного початку - всебічного емпіричного сприйняття. Однак слід розуміти, що навіть всебічна поінформованість у предметі й процесі на рівні емпіричного знання $\epsilon$ неповним, неглибоким, поверховим знанням, оскільки воно фіксує саме те, що безпосередньо потрапляє в коло зору і знаходить вираз у почуттях, спостереженнях і уявленнях. Таким чином, емпіричне знання не $є$ багатим і всебічним не тільки з вигляду, але й за своєю суттю ${ }^{6}$.

Налаштування свідомості дослідника на включення функції абстрактного мислення таким чином пов'язана зі специфічним сприйняттям конкретно-емпіричного матеріалу, щоб уникнути спокуси загрузнути в емпіричній схоластиці. 3 іншого боку, існує проблема «порожніх абстракцій». В економічній науці ці відхилення від золотої середини спостерігаються в усі час іiі існування. Це відбивається також в поділ на теоретиків і практиків, кабінетних вчених і підприємців і так далі. Вирішення цієї проблеми полягає в методології самого спостереження. Перш за все це позиція безоціночного спостерігача, який знаходиться в онтологічному статусі дослідника, а не обмеженого своїми уявленнями й ідеологією апологета. Далі це різноплановість і багатоканальність спостережень чим більше різнорідних каналів, за якими прийшла інформація, тим менше спотворень. Поступово накопичена у процесі глибокого і широкого спостереження кількість спостережень переходить в якість теоретичного узагальнення. При цьому слід підкреслити, що важлива особлива підготовка розуму з розвитку чуйного тонкого розрізнення, що дозволяє вловлювати ідеї-абстракції явищ. Про це говорив B.I. Вернадський ${ }^{7}$, який вказує на софійність знань.

В економічних дослідженнях використання абстрактного мислення у зв'язку з конкретно історичними умовами має як онтологічні передумови, так і певні конкретні форми у вигляді методології та практик організаційно-діяльнісних ігор Г.П. Щедровицького. Більш широке

\footnotetext{
${ }^{1}$ Щедровицкий, Г. П. (2004). Московский методологический кружок: развитие идей и подходов. Москва: Из архива Г.П. Щедровицкого, 8,1 .

${ }^{2}$ Громыко, Ю. В. (1991). Московская методологическая школа: социокультурные условия возникновения, идейное содержание, проблемы развития. Вопросы методологии, 4.

${ }^{3}$ Мещеряков, А. И. (1974). Слепоглухонемые дети. Развитие психики в прочессе формирования поведения. Москва: Педагогика.

${ }^{4}$ Ильенков, Э. В. (1970). Психика человека под «лупой времени». Природа, 1, 88-91.

${ }^{5}$ Бехтерева, Н. П. (1988). Здоровый и больной мозг человека. Ленинград: Наука.

${ }^{6}$ Покрытан, А. К. (2001). Методические указания по изучению курса "Политическая экономия". Метод политической экономии для аспирантов и студентов 5 курса всех форм обучения, всех специальностей. Одесса: ОГЭУ.

${ }^{7}$ Вернадский, В. И. (1978). Живое вещество. Москва: Наука, 131-134.
} 
використання даної методології в процесі багаторічної практики здатні істотно підвищити гносеологічний потенціал економічної науки як в цілому, так і їі окремих напрямків.

Розкриття гносеологічного потенціалу онтології та діалектики в контексті їх інтеграції з сучасними напрямками пізнання розкриває певні можливості подальшого розвитку наукового пізнання економічної системи капіталу в контексті предметної глибини i міждисциплінарної інтеграції. Найбільш повне пізнання й осмислення економічної системи можливо на найзагальнішому абстрактному рівні - рівні онтології буття. 3 позиції онтології можливо не тільки осмислити й пізнати економічну систему, а й обгрунтувати умови ії розвитку. Цільовою функцією системної стійкості, гармонії і розвитку економіки $є$ онтологічна повнота. Тобто комплексний напрямок економічної політики і господарської практики на подолання онтологічної недостатності є умовою економічного розвитку. В будь-якій дослідницькій галузі існує особливе коло проблем, пізнати і осмислити які можливо на найзагальнішому рівні абстракції - на рівні протікання буття або онтологічному рівні. Не $\epsilon$ винятком і економічна теорія.

Співвідношення онтології та діалектики в пізнанні капіталу надає можливості розкриття буттєвих джерел актуалізації буття капіталу і його подальшого руху, пов'язаного з дією системи діалектичних протиріч. Онтологія - вчення про суще; вчення про буття як таке, що вивчає фундаментальні принципи буття, його найбільш загальні сутності й категорії, структуру i закономірності ${ }^{1}$. До онтологічних проблем у пізнанні капіталу можна віднести співвідношення чистого буття i форм його руху в дійсності. В рамках дослідницького напрямку філософія господарства ${ }^{2}$ розкриває зміст процесів, що протікають в економічній системі та які розкривають шляхи для істотних змін. Філософія господарства, на відміну від багатьох інших напрямків економічної науки, чітко визначає мету функціонування господарської системи. При цьому наголошує на тому, що мета ії функціонування виходить за рамки економіки. Економічна система розуміється не як самоцінне, а як функціональна громадська система. Ідея, яку відзначав Б. Вишеславцев ${ }^{3}$, критикуючи «економізм», як надання економічній системі самоцінності й дуже перебільшеної важливості, значно обмежує можливості дослідження.

Згідно постановок філософії господарства основною метою існування як світу в цілому, так і економічної системи є обоження або духовне перетворення. Обоження, або теозис, - християнське вчення про з'єднання людини з Богом, прилучення людини до божественного життя через дію божественної благодаті ${ }^{4}$. У філософії господарства розглядається поняття повноти буття як окремої людини, так і господарської системи. Повнота буття окремої людини визначає повноту буття всієї системи як цілісності. Таким чином, чим більше повнота буття окремої людини, тобто ступеня свідомої волі або каналів сприйняття, тим більш стійкою і розвиненою буде система. 3 цього може випливати ідея подолання соціонічних обмежень, які превалюють у сучасному суспільстві, забезпечуючи умови розширення для різних форм експлуатації, професійного ідіотизму, сімулякрізації та фетишизму. У контексті філософії господарства спрямованість людини до повноти буття - основа енергії будь-якої господарської системи. Крім того, дослідження співвідношення онтологічної повноти й онтологічної недостатності на різних етапах розвитку економіки і людини надає можливості для обгрунтування онтологічної основи щодо визначення інноваційної чутливості та інерції економічної системи.

Висновки. Здійснено теоретичну ревізію і рефлексію теорії основного капіталу в традиції економічної думки. Використовуючи економіко-герменевтичний аналіз досліджені історичні контексти формування теорії основного капіталу в цілому і окремих її граней. Досліджено ключові розумові ходи, які зробили істотний внесок у формування теорії основного капіталу. Реактуалізовано місце теорії основного капіталу в традиції економічній думці. Продемонстровано причини існуючого методологічного плюралізму в теорії основного капіталу. Досліджено роль і можливості застосування розумового експерименту в теорії основного капіталу. Поставлені проблеми онтологічних i антропологічних розривів економічного знання в аспекті їх впливу на теорію основного капіталу. Матеріал роботи може бути використаний в подальших економіко-теоретичних розробках, що ведуться в дискурсі проблем відтворення основного капіталу.

\footnotetext{
1 Доброхотов, А. Л. (2010). Онтология. Новая философская энииклопедия, 345

2 Булгаков, С. Н. (2009). Философия хозяйства. Москва: Институт русской цивилизации.

${ }_{3}^{3}$ Вышеславцев, Б. П. (1953). Кризис индустриальной культуры. Нью-Йорк: Chalidz Publications.

${ }^{4}$ Ваганова, Н. А. (2011). Софиология протоиерея Сергия Булгакова. Москва: ПСТГУ.
} 


\section{References:}

1. Bibler, B. C. (1975). Myshleniye kak tvorchestvo [Thinking as creativity]. Moscow: Politizdat. [in Russian].

2. Medintsev, V. A. (2018). Myshleniye teoretika novogo vremeni [Thinking of the theorist of modern times]. Vosmaya mezhdunarodnaya konferentsiya po kognitivnoy nauke: Tezisy dokladov. Svetlogorsk, 18-21 oktyabrya 2018 g. Moskva [Eighth International Conference on Cognitive Science: Abstracts. Svetlogorsk, October 18-21, 2018]. Moscow: Institute of Psychology RAS. [in Russian].

3. Ulybin, K. A. (1989). Sovremennoye ekonomicheskoye myshleniye: politiko-ekonomicheskiye aspekty issledovaniya i formirovaniya [Modern economic thinking: political and economic aspects of research and formation]: avtoreferat dissertatsii na soiskaniye nauchnoy stepeni doktora ekonomicheskikh nauk [thesis abstract for the degree of Doctor of Economics]. Moscow: Institute of Economics of the USSR Academy of Sciences. [in Russian].

4. Arkhipov, A. Yu. (1999). Sovremennoye ekonomicheskoye myshleniye (Voprosy teorii i praktiki razvitiya): [Modern economic thinking (Questions of theory and practice of development)]: dissertatsiya na soiskaniye nauchnoy stepeni doktora ekonomicheskikh nauk [dissertation for the degree of Doctor of Economics]. Rostov-on-Don: Rostov State University. [in Russian].

5. Heine, P. (1991). Ekonomicheskiy obraz myshleniya [An economic way of thinking]. Moscow Libertarium <http://libertarium.ru/lib_thinking> (2021, August, 31). [in Russian].

6. Blaug, M. (2004). Metodologiya ekonomicheskoy nauki, ili Kak ekonomisty obyasnyayut [Methodology of Economics, or As Economists Explain]. Moscow: Journal of Economics. [in Russian].

7. Blaug, M. (1994). Ekonomicheskaya zhizn v retrospektive [Economic life in retrospect]. Moscow: Delo Ltd. [in Russian].

8. Fisher S., Rudiger D., Schmalenzi R. (1995). Ekonomika [Economy]. Moscow: Delo Ltd. [in Russian].

9. Chernetskaya, N. I. (2011). Tipologicheskiy i urovnevyy podkhody k myshleniyu kak teoretiko-metodologicheskiye osnovaniya integral'noy kontseptsii tvorcheskogo myshleniya [Typological and level approaches to thinking as theoretical and methodological foundations of the integral concept of creative thinking]. Vestnik Surgutskogo gosudarstvennogo pedagogicheskogo universiteta [Bulletin of the Surgut State Pedagogical University], 3, 5-9. [in Russian].

10. Korkotsenko, M. N. (2017). Obzor opredeleniy kategorii «ekonomicheskoye myshleniye» [Review of definitions of the category "economic thinking"]. Teoriya i praktika obshchestvennogo razvitiya [Theory and practice of social development], 2. DOI: https://doi.org/10.24158/tipor.2017.2.10. [in Russian].

11. Ilyenkov, E. V. (1997). Dialektika abstraktnogo i konkretnogo v nauchno-teoreticheskom myshlenii [Dialectics of the abstract and the concrete in scientific and theoretical thinking]. Moscow: ROSSPEN. [in Russian].

12. Humboldt W. von (2011). O vnutrenney $i$ vneshney organizatsii vysshikh nauchnykh uchrezhdeniy v Berline [On the internal and external organization of higher scientific institutions in Berlin]. Moscow: The University Idea in the Russian Empire in the 18th and early 20th centuries: an anthology. [in Russian].

13. Newman, J. G. (2006). Ideya Universiteta [The idea of the University]. Minsk: BSU. [in Russian].

14. Jaspers, K. (2006). Ideya universiteta [The idea of a university]. Minsk: BSU. [in Russian].

15. Lektorsky, V. A. (2010). Myshleniye. Novaya filosofskaya entsiklopediya: V 4 tomakh [Thinking. New Encyclopedia of Philosophy: In 4 volumes]. Moscow: Thought, II. [in Russian].

16. Shchedrovitsky, G. P. (2004). Moskovskiy metodologicheskiy kruzhok: razvitiye idey i podkhodov [Moscow Methodological Circle: Development of Ideas and Approaches]. Moscow: From the archive of G.P. Shchedrovitsky, 8, 1. [in Russian].

17. Gromyko, Yu. V. (1991). Moskovskaya metodologicheskaya shkola: sotsiokul'turnyye usloviya vozniknoveniya, ideynoye soderzhaniye, problemy razvitiya [Moscow methodological school: socio-cultural conditions of origin, ideological content, development problems]. Voprosy metodologii [Methodological issues], 4. [in Russian].

18. Meshcheryakov, A. I. (1974). Slepoglukhonemyye deti. Razvitiye psikhiki v protsesse formirovaniya povedeniya [Deaf-blind children. The development of the psyche in the process of the formation of behavior]. Moscow: Pedagogy. [in Russian].

19. Ilyenkov, E. V. (1970). Psikhika cheloveka pod «lupoy vremeni» [The human psyche under the "magnifying glass of time"]. Priroda [Nature], 1, 88-91. [in Russian].

20. Bekhtereva, N. P. (1988). Zdorovyy i bolnoy mozg cheloveka [Healthy and diseased human brain]. Leningrad: Science. [in Russian].

21. Pokrytan, A. K. (2001). Metodicheskiye ukazaniya po izucheniyu kursa "Politicheskaya ekonomiya" [Methodical instructions for studying the course "Political Economy"]. Metod politicheskoy ekonomii dlya aspirantov $i$ studentov 5 kursa vsekh form obucheniya, vsekh spetsialnostey [The method of political economy for graduate students and 5th year students of all forms of education, all specialties]. Odessa: OGEU. [in Russian].

22. Vernadsky, V. I. (1978). Zhivoye veshchestvo [Living substance]. Moscow: Science. [in Russian].

23. Dobrokhotov, A. L. (2010). Ontologiya [Ontology]. Novaya filosofskaya entsiklopediya [New Philosophical Encyclopedia]. Moscow. [in Russian].

24. Bulgakov, S. N. (2009). Filosofiya khozyaystva [Economy philosophy]. Moscow: Institute of Russian Civilization. [in Russian]. 
25. Vysheslavtsev, B. P. (1953). Krizis industrialnoy kultury [Industrial culture crisis]. New York: Chalidz Publications. [in Russian].

26. Vaganova, N. A. (2011). Sofiologiya protoiyereya Sergiya Bulgakova [Sophiology of Archpriest Sergius Bulgakov]. Moscow: PSTGU. [in Russian]. 